\title{
Floating Aquatic Macrophytes Decrease the Methane Concentration in the Water Column of a Tropical Coastal Lagoon: Implications for Methane Oxidation and Emission
}

\author{
André Luiz dos Santos Fonseca ${ }^{1}$, Claudio Cardoso Marinho ${ }^{2}$, Franscisco de Assis \\ Esteves ${ }^{3}$. \\ ${ }^{I}$ Instituto Federal de Educação, Ciência e Tecnologia do Rio de Janeiro, Realengo. , Rio de Janeiro, Brasil; \\ ${ }^{2}$ Universidade Federal do Rio De Janeiro - Ecologia, Rio de Janeiro, Brazil; ${ }^{3}$ Universidade Federal do Rio de \\ Janeiro - Núcleo em Ecologia e Desenvolvimento Sócio-Ambiental de Macaé, Macaé, Rio de Janeiro, Brasil.
}

\begin{abstract}
In wetlands, the knowledge accumulated on the role of aquatic plants in the methane cycle focused on emergent macrophytes, to the detriment of other typologies. Herein, we evaluated whether the free-floating macrophyte Salvinia auriculata Aubl. and the floating-leaved macrophyte Eichhornia azurea (Sw.) Kunth. decrease the water column methane concentrations compared to a plant-free surface. We prepared microcosms by inserting an individual of $\mathrm{S}$. auriculata or of $\mathrm{E}$. azurea into chambers filled with lagoon water previously bubbled with $\mathrm{CH}_{4}$. Another set of chambers was incubated only with the prepared water, representing the plant-free surface. Half of the chambers were kept in the dark and half in sunlight to simulate a diel cycle. We observed greater loss of $\mathrm{CH}_{4}$, higher $\mathrm{O}_{2}$ uptake and lower $\mathrm{CO}_{2}$ outflow in the plants treatments. The decrease in methane concentrations in the E. azurea treatments was $93.5 \%$ in the light and $77.2 \%$ in the dark. In the S. auriculata treatments, the decreases were $74.2 \%$ and $67.4 \%$ in the light and in the dark, respectively. In plant-free surface the decrease was $58.7 \%$ in the light and $36.3 \%$ in the dark. These results indicate a role of floating aquatic macrophytes in the methane cycle in the water column. Moreover, our results suggest a diel variation of methane oxidation and methane emission, according to the differences observed in $\mathrm{O}_{2}$ uptake and $\mathrm{CO}_{2}$ outflow between dark and light conditions. Thus, future predictions of global methane budget should include the role played by floating aquatic macrophytes.
\end{abstract}

Key words: methane, eutrophication, global warming, Eichhornia azurea, Salvinia auriculata.

\footnotetext{
*Author for correspondence: andre.fonseca@ifrj.edu.br
} 


\section{INTRODUCTION}

Methane $\left(\mathrm{CH}_{4}\right)$ is one of the major greenhouse gases (GHG) present in the atmosphere, contributing to global warming ${ }^{1}$. Natural wetlands are the single largest source of atmospheric methane, but their estimated emissions present considerable uncertainties, varying from 177 to $284 \mathrm{Tg} \mathrm{CH}_{4}$ annually, which represents $33.7-$ $34.2 \%$ of global methane emission ${ }^{2}$. The variation in the amount of methane emitted in wetlands reflects the balance between methanogenesis and methanotrophy ${ }^{3}$. These processes involve complex interactions between plants and microorganisms in heterogeneous environments, resulting in variations in the methane emission at the scale of hours and meters ${ }^{4}$. In addition to these interactions, we must also consider the importance of the emission through hydrodynamic processes at the air-water interface. Hydrodynamic transport includes both molecular diffusion and advective processes, which are controlled by physical variables such as wind, temperature, thermal convection, current velocity, waves and bubbles ${ }^{5,6}$. In this scenario, the vegetation contribution to the global methane budget is one of the least understood 7. Considering the key role of methane in the global climate change and the uncertainties in methane emission determinations in wetlands is essential identify and quantify all sources and driving processes related to methane flux to the atmosphere.

Shallow wetlands, such as coastal lagoons, usually have broad colonization by aquatic macrophytes ${ }^{8}$. These plants can influence methane cycle in wetlands through the mechanisms of production, consumption and transport of methane ${ }^{9}$. First, aquatic macrophytes release organic matter from root exudates and from the decaying litter, providing substrates for methane production in the anoxic sediments $10,11,12$. Second, plants may reduce a large and variable proportion (1-90\%) of methane produced in the sediment through the oxidation in the rhizosphere ${ }^{13,14,15}$. Third, plant aerenchyma may act as a conduit by which methane is conducted from the sediment to the atmosphere ${ }^{16}$. Most of the methane is emitted through the aerenchyma of emerged plants in shallow wetlands $9,17,18$

So far, the scientific knowledge accumulated on the role of aquatic macrophytes in the methane cycle in wetlands focused on emergent macrophytes 9, 10, 12, 19, 20. Wetlands vary greatly in aquatic macrophytes species composition, comprising diverse typologies, such as emergent, floating-leaved, submerged rooted, submerged free and free-floating ${ }^{8}$. However, in eutrophic environments, apart from colonization by emergent aquatic macrophytes, the floating-leaved and free-floating plants are benefited over submerged forms ${ }^{21,22}$. The shift in the plants community structure in eutrophic ecosystems significantly changes the dissolved gases dynamics ${ }^{23}{ }^{24}$. The floating plants release the oxygen produced during photosynthesis directly to the atmosphere ${ }^{25}$. At the same time, the floating leaves hinder the light penetration into the water, limiting the phytoplanktonic photosynthesis, as well as the diffusion of $\mathrm{O}_{2}$ from the atmosphere, thereby promoting water anoxia below the leaves ${ }^{26,27}$. The floating leaves also represent a barrier against the escape of methane and carbon dioxide $\left(\mathrm{CO}_{2}\right)$ to the atmosphere, so supersaturation of these gases in the water column is expected ${ }^{23,28}$. Despite the concerns about floating-leaved and free-floating aquatic macrophytes in eutrophied environments, the role of these plants in reducing the methane concentration in wetlands, encompassing emission through the leaves and oxidation in the rhizosphere, has not been assessed.

In this study, we aim at evaluating whether the free-floating macrophyte Salvinia auriculata and the floating-leaved macrophyte Eichhornia azurea diminishes the concentration of methane in the water column compared to a plant-free surface through short-term experiment in microcosms. We hypothesize that the aquatic macrophytes have positive effect on methane concentration decrease in water 
column. We then hypothesized that the influence of macrophytes follows a diel pattern, depending on the light incidence. These issues are relevant at a larger scale due to two main reasons. First, freshwater shore zones have been heavily damaged by human activities historically ${ }^{29}$. The major problem in these densely populated areas is the pollution by liquid and solid wastes ${ }^{30}$, generating the eutrophication of water bodies ${ }^{8}$. Second, the climate change, particularly global warming, is expected to increase the eutrophication process in shallow coastal lagoons 31, 32. The interaction between eutrophication and climate change could result in a positive feedback loop, as eutrophication promotes the increase in the emission of greenhouse gases into the atmosphere, contributing to global warming. In turn, the global warming contributes to the magnification of eutrophication, since the unequivocal increase in the sea level may lead to a decrease in the amount of light reaching the bottom of the lagoons. This light attenuation exists as a result of the decrease in water column transparency caused by the suspended solids runoff and the increase in nutrient inputs ${ }^{31,32}$.

\section{MATERIALS AND METHODS}

Aquatic macrophytes and water samples utilized in the experiment were collected in Cabiúnas Lagoon ( $\left.22^{\circ} 15^{\prime} \mathrm{S}, 41^{\circ} 40^{\prime} \mathrm{W}\right)$, located at Restinga de Jurubatiba National Park, Rio de Janeiro, Brazil (Fig. 1). Cabiúnas is a pristine freshwater coastal lagoon with a surface area of $0.34 \mathrm{~km}^{2}$ and a mean depth of $2.37 \mathrm{~m}^{33}$. The water is oligotrophic, humic (13 mg C L $\mathrm{mg}^{-1}$ of dissolved organic carbon, DOC) and slightly acidic ( $\mathrm{pH}$ 6.3) and has an average annual temperature of $23.6{ }^{\circ} \mathrm{C}{ }^{34}$. The large perimeter/volume ratio and the dendritic shape enable the dense development of aquatic macrophytes communities in its margins ${ }^{33}$, covering $60 \%$ of its area ${ }^{35}$. Regarding the study of the methane cycle, an earlier study did not observe the presence of methane in Cabiúnas Lagoon ${ }^{36}$. On the other hand, the monthly monitoring of this environment between 2001 and 2003 revealed the presence of methane in the entire period of study, with a maximum value reaching approximately $12 \mu \mathrm{mol} \mathrm{L}{ }^{-137}$. 

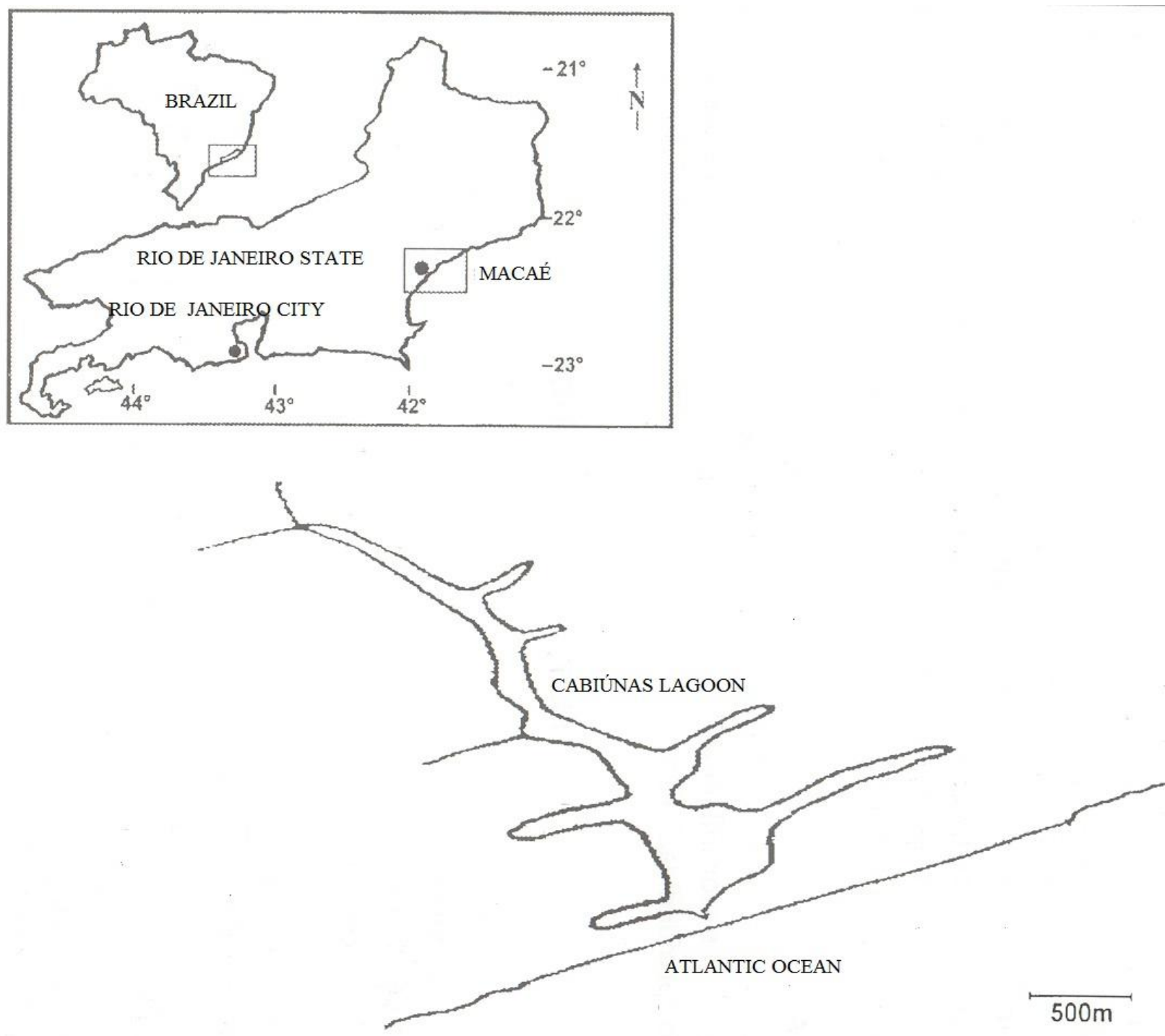

Figure 1 - Schematic map of Cabiúnas lagoon location on the Restinga de Jurubatiba National Park at Macaé, in the Northern region of Rio de Janeiro State (22 $24^{\prime}$ S and $41^{\circ} 42^{\prime}$ W).

We collected samples of the floating-leaved aquatic macrophyte E. azurea and of the free floating aquatic macrophyte $S$. auriculata and placed them in a plastic container with lagoon water. Samples of E. azurea were detached from the parent stem, keeping the adventitious roots attached to the individual collected. Although this procedure has caused damage to individuals collected, the detachment and subsequent displacement and anchoring of the plants is a common event in flood pulses. The water samples were collected with polyethylene gallons $(\sim 80 \mathrm{~L})$ in the water column below the leaves of plants.

Approximately two hours after sampling, the water samples were filtered through plankton net with mesh size of $25 \mu \mathrm{m}$ to remove coarse organic matter, which could alter the results of incubations. After filtration, the water was prepared by bubbling methane with a silicone hose dipped in the water and connected to a methane cylinder for 20 minutes for the dissolution of gas. Next, we established 36 experimental chambers (glass vials, volume of $3 \mathrm{~L}, 26 \mathrm{~cm}$ long x $13 \mathrm{~cm}$ internal diameter) containing $2 \mathrm{~L}$ of the prepared water, carefully introduced into the chambers. The treatments established were 12 chambers with of 1 individual of $E$. azurea, 12 chambers with 1 individual of $S$. auriculata and 12 chambers without 
plants (plant-free surface). The initial methane concentration after preparation of the chambers was $136 \mu \mathrm{mol} \mathrm{L} \mathrm{L}^{-1}$. The methane concentration used in the experiment was about ten times higher than that found in the environment. In the environment there is a constant supply of methane from the sediment, which maintains methane in the water without interruption. In the experiment was necessary dissolving a large amount of methane at once because the tendency is the rapid loss of the gas, since there is no source of renewal. Half of the chambers of each treatment was kept in the dark condition in the laboratory in a pool containing tap water and the other half was kept in the light condition (under the sun) in other pool also containing tap water. The pool with water kept the experiment under controlled temperature $\left(23 \pm 2{ }^{\circ} \mathrm{C}\right)$, according the average temperature found in the lagoon ${ }^{34}$. We decided to use the same temperature for dark and light conditions because we aimed to assess the effect of light intensity and not the effect of temperature on methane concentrations.

The chambers were incubated for 12 hours, with sampling to determine the concentrations of methane in the following intervals: $0,2,4,6$ and $12 \mathrm{~h}$. In each sampling, the water was collected from each chamber using plastic syringes and needles. The tip of the syringe was dipped into the water close to the roots and the plunger was pulled slowly removing the aliquot of $8 \mathrm{~mL}$ of water. After collecting water, the syringe was connected to a needle and the water was injected into an evacuated glass flask of $12 \mathrm{~mL}$ closed with rubber stoppers, containing the equivalent of $20 \%$ (weight/volume) of $\mathrm{NaCl}$. Under this condition methane is degassed into the head space. The samples were kept under refrigeration in the laboratory and analyzed $48 \mathrm{~h}$ later. The degassing with $\mathrm{NaCl}$, the cooling and analysis in this short time minimize interference in the sample results. The methane content of the head space was quantified using a gas chromatograph (Star $3400-$ Varian Co., EUA) and the operation conditions were FID detector temperature 200 ${ }^{\circ} \mathrm{C}$, injector temperature $120{ }^{\circ} \mathrm{C}$ and a $3 \mathrm{~m}$ Poropak-N column (80/100 mesh) at 85 ${ }^{\circ} \mathrm{C}$ and $\mathrm{N}_{2}$ as the carrier gas. Photosynthetically active radiation (PAR) was monitored in light and dark in every time of water sampling using a radiometer (LICOR - model LI-1000).

The $\mathrm{CO}_{2}$ concentrations were determined from measurements of $\mathrm{pH}$ and alkalinity, using ALCAGRAN software ${ }^{38}$. $\mathrm{pH}$ was measured with a precision of $0.01 \mathrm{pH}$ units using a Analion PM $608 \mathrm{pH}$ meter and total alkalinity by Gran's titration ${ }^{39} \cdot \mathrm{O}_{2}$ concentrations were determined with a digital oxymeter (YSI-55). The $\mathrm{pH}$ values, $\mathrm{CO}_{2}$ and $\mathrm{O}_{2}$ concentrations in each chamber were determined at the beginning and at the end of the experiment to evaluate the variation in $\mathrm{pH}$ values, the $\mathrm{CO}_{2}$ flux and the $\mathrm{O}_{2}$ consumption, respectively.

The methane concentrations (dependent variable) of each region (aquatic macrophytes species and plant-free surface) and condition (light and dark) (categorical variables) per sample time (continuous variable) were compared using an analysis of covariance (ANCOVA; significance level of 0.05), followed by Tukey's HSD test to determine which groups are particularly different from each other. At each sampling time, 1 sample was collected from each flask $(n=6)$ to the methane concentration analysis. The dissolved oxygen and carbon dioxide (dependent variable) values were tested using one-way analysis of variance (ANOVA; significance level of 0.05) between sites conditions (categorical variables), followed by Tukey's HSD test to determine which groups are different. For the analysis of dissolved oxygen and carbon dioxide, 1 sample was collected from each flask $(n=6)$ at the beginning and at the end of the experiment.

\section{RESULTS}


Methane concentration decrease was significantly higher in treatments with plants than in the plant-free surfaces, both in light and in the dark conditions (Fig. 2; Table 1), indicating a positive effect of the aquatic macrophytes studied on the decrease of methane concentration in the water column. There were no significant differences between the plants in light and in the dark (Fig. 2; Table 1). The plant-free surfaces also presented methane concentration decrease with nonsignificant differences between light and dark conditions (Fig. 2; Table 1). The decrease in methane concentrations at the end of the experiment in the treatments with E. azurea was $93.5 \%$ in the light and $77.2 \%$ in the dark. In the treatments with $S$. auriculata, the decreases were $74.2 \%$ and $67.4 \%$ in the light and in the dark, respectively. In plantfree surface treatments the decrease was $58.7 \%$ in the light and $36.3 \%$ in the dark.
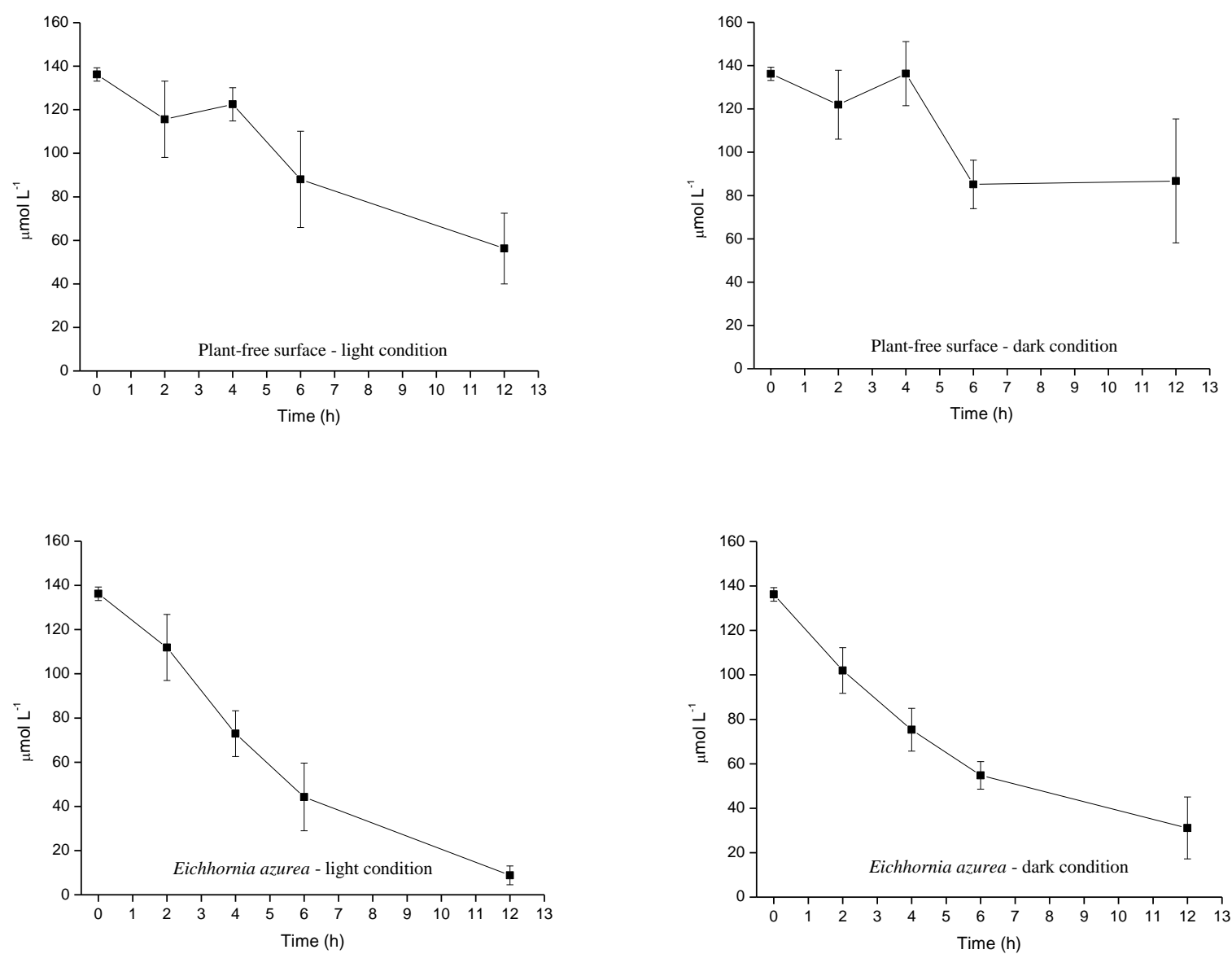

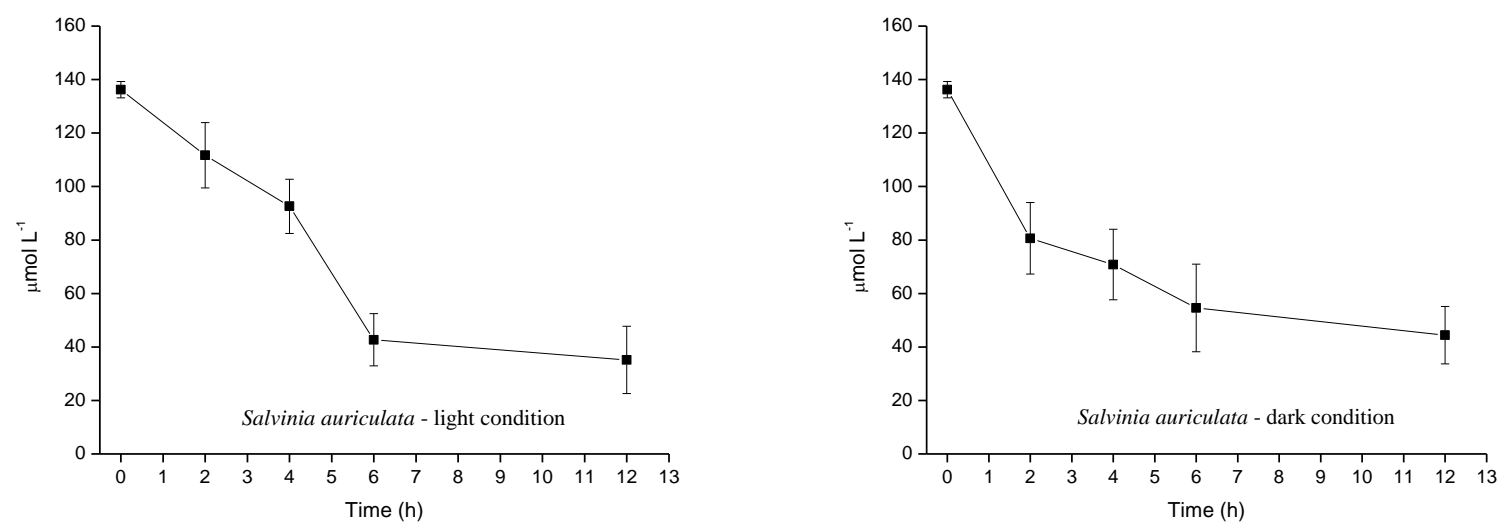

Figure 2 - Temporal variation of water $\mathrm{CH}_{4}$ concentrations $\left(\mu \mathrm{mol} \mathrm{L}{ }^{-1}\right)$ in the plant-free surface and in the treatments with aquatic macrophytes in the light and in the dark conditions. Bars $=$ standard deviation.

Table 1 - Values of significance (p) of ANCOVA test, number of samples (n), degrees of freedom (DF) and values of deviance $(\mathrm{F})$, between regions, conditions and regions-conditions interactions for $\mathrm{CH}_{4}$ concentrations. Values of significance (p) of Tukey's HSD test between regions in light and dark conditions and between conditions in each region for $\mathrm{CH}_{4}$ concentrations.

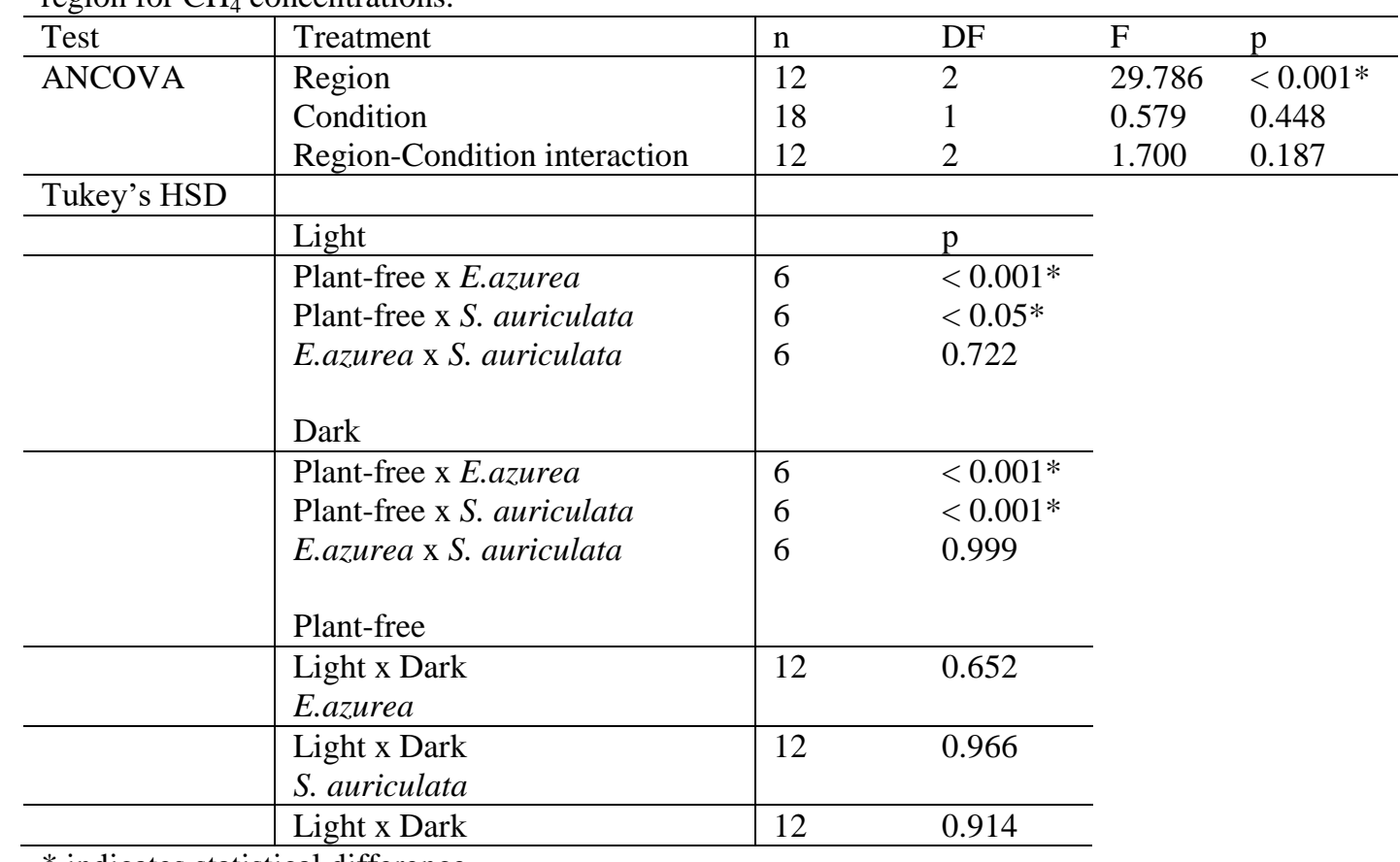

Oxygen consumption was significantly higher in treatments with plants than in the plant-free surface only in the dark (Fig. 3; Table 2), being 4.0 times higher on treatment with E. azurea and 13.6 times higher in the treatment with S. auriculata. In the comparison between plants was observed significantly higher consumption of oxygen (Fig. 3; Table 2) in the treatment with S. auriculata in the dark. The oxygen consumption in the three regions was always higher in the dark, but significant difference (Fig. 3; Table 2) was observed only in treatment with $S$. auriculata.

Conversely, the loss of $\mathrm{CO}_{2}$ in the treatments with plants was significantly lower than in the plant-free surface in the dark (Fig. 4; Table 3), being 6.8 times lower in the treatment with E. azurea and 1.8 times lower in the treatment with $S$. auriculata. 
In the light, the loss of $\mathrm{CO}_{2}$ was significantly lower than plant-free surface only in $S$. auriculata treatment (Fig. 4; Table 3), being 1.2 times lower. S. auriculata presented significantly lower $\mathrm{CO}_{2}$ loss (Fig. 4; Table 3) than E. azurea only in the dark. In each region, the loss of $\mathrm{CO}_{2}$ was always lower in the dark and, significant differences (Fig. 4; Table 3) were observed in both treatments with plants.

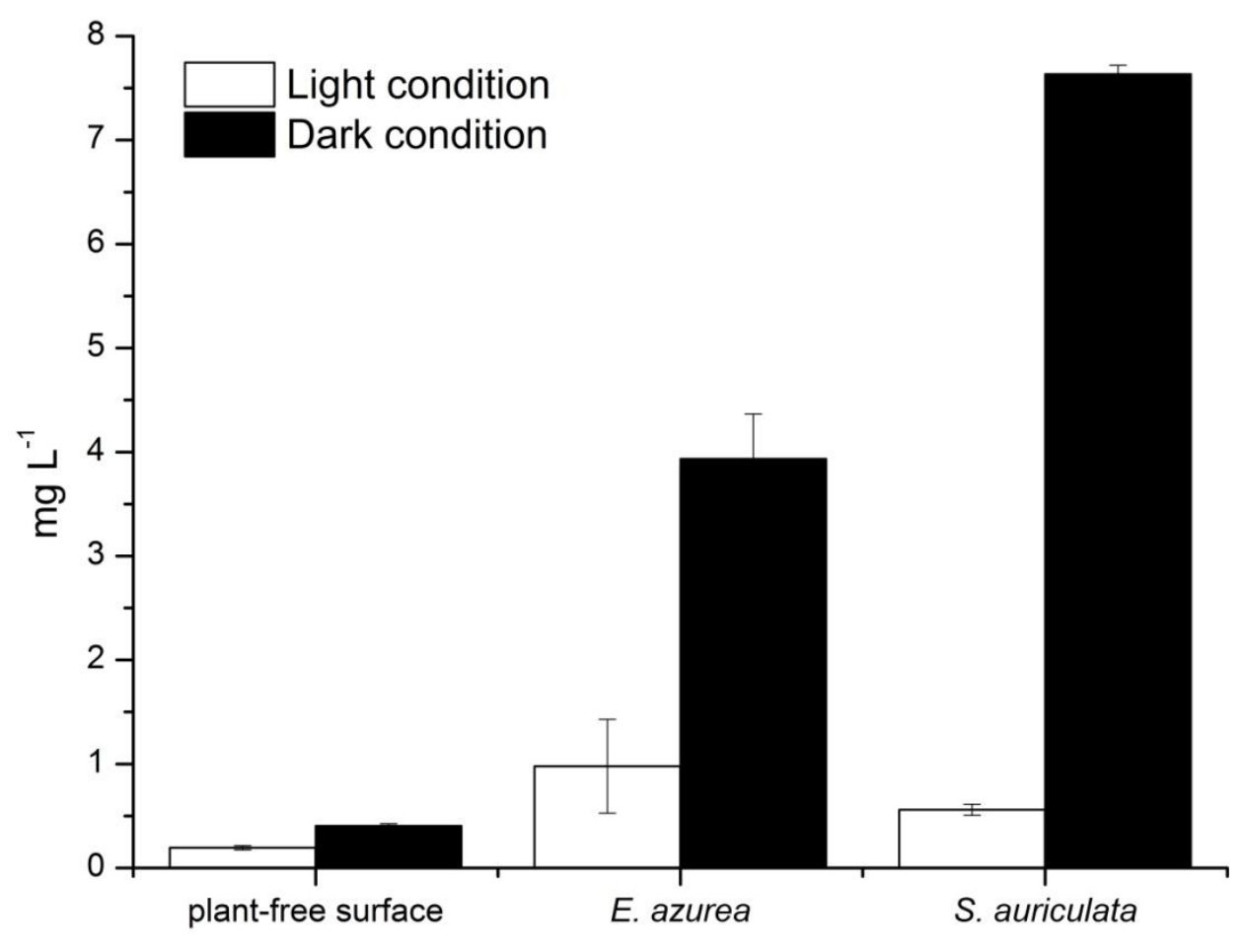

Figure $3-\mathrm{O}_{2}$ consumption $\left(\mathrm{mg} \mathrm{L}^{-1}\right.$ ) (difference between the values at the beginning and at the end of the experiment) in the plant-free surface and in the treatments with aquatic macrophytes in the light and in the dark conditions. Bars = standard deviation.

Table 2 - Values of significance (p) of ANOVA test, number of samples (n), degrees of freedom (DF) and values of deviance $(\mathrm{F})$, between regions, conditions and regions-conditions interactions for $\mathrm{O}_{2}$ concentrations. Values of significance (p) of Tukey's HSD test between regions in light and dark conditions and between conditions in each region for $\mathrm{O}_{2}$ concentrations.

\begin{tabular}{|c|c|c|c|c|c|}
\hline Test & Treatment & $\mathrm{n}$ & $\mathrm{DF}$ & $\mathrm{F}$ & $\mathrm{p}$ \\
\hline \multirow[t]{3}{*}{ ANOVA } & Region & 12 & 2 & 15.736 & $<0.001 *$ \\
\hline & Condition & 18 & 1 & 23.663 & $<0.001 *$ \\
\hline & Region-Condition interaction & 12 & 2 & 13.413 & $<0.001 *$ \\
\hline \multicolumn{6}{|c|}{ Tukey's HSD } \\
\hline & Light & \multicolumn{2}{|r|}{$\mathrm{p}$} & & \\
\hline & Plant-free x E.azurea & 6 & \multicolumn{3}{|l|}{0.205} \\
\hline & Plant-free x S. auriculata & 6 & \multicolumn{3}{|l|}{0.999} \\
\hline & E.azurea x S. auriculata & 6 & \multicolumn{3}{|l|}{0.341} \\
\hline & \multicolumn{3}{|l|}{ Dark } & & \\
\hline & Plant-free x E.azurea & 6 & $<0.05^{*}$ & & \\
\hline & Plant-free x S. auriculata & 6 & $<0.001 *$ & & \\
\hline & E.azurea x S. auriculata & 6 & $<0.05^{*}$ & & \\
\hline
\end{tabular}


Macrophytes Decrease Methane in a Lagoon

\begin{tabular}{l|l|lc} 
& Plant-free & & \\
\hline & $\begin{array}{l}\text { Light x Dark } \\
\text { E.azurea }\end{array}$ & 12 & 0.999 \\
\hline & $\begin{array}{l}\text { Light x Dark } \\
\text { S. auriculata }\end{array}$ & 12 & 0.820 \\
\hline & Light x Dark & 12 & $<0.001^{*}$ \\
\hline
\end{tabular}

* indicates statistical difference.

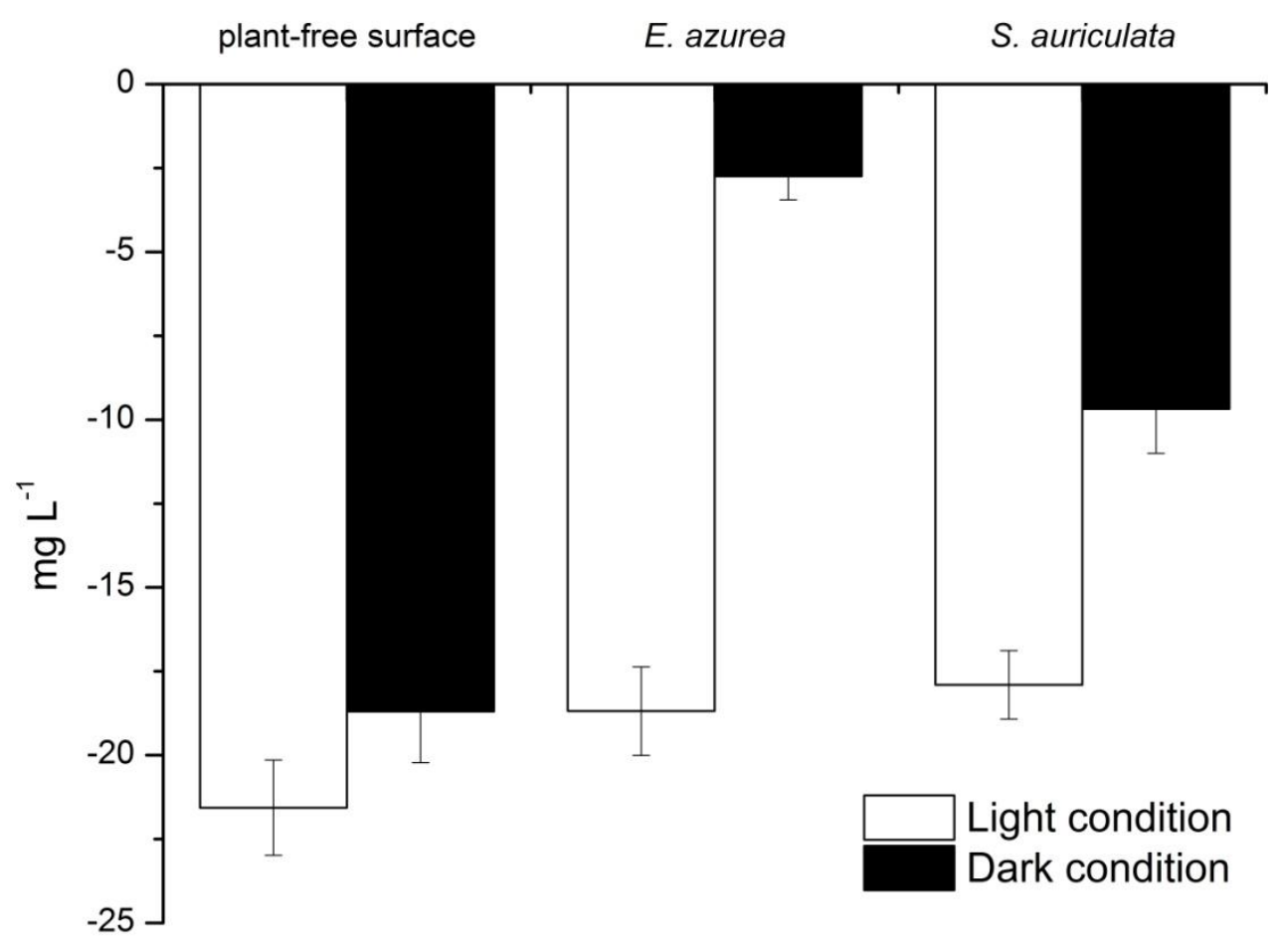

Figure 4 - $\mathrm{CO}_{2}$ loss $\left(\mathrm{mg} \mathrm{L}^{-1}\right)$ (difference between the values at the beginning and at the end of the experiment) in the plant-free surface and in the treatments with aquatic macrophytes in the light and in the dark conditions. Bars $=$ standard deviation.

Table 3 - Values of significance (p) of ANOVA test, number of samples (n), degrees of freedom (DF) and values of deviance $(\mathrm{F})$, between regions, conditions and regions-conditions interactions for $\mathrm{CO}_{2}$ concentrations. Values of significance $(p)$ of Tukey's HSD test between regions in light and dark conditions and between conditions in each region for $\mathrm{CO}_{2}$ concentrations.

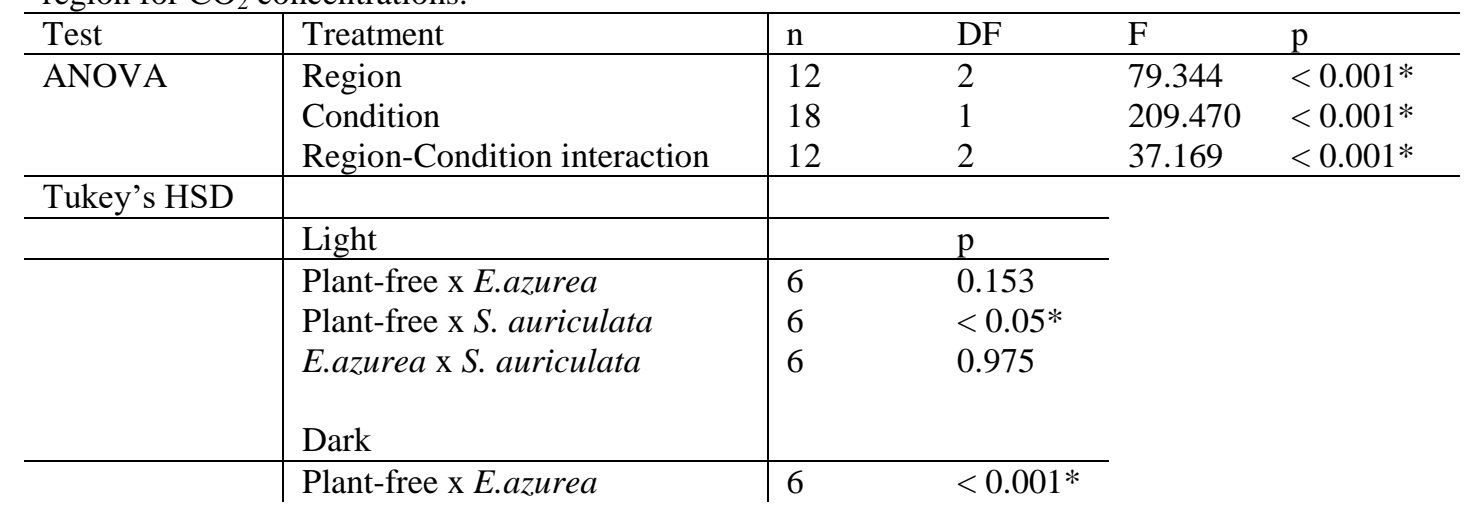




\begin{tabular}{l|l|lc} 
& Plant-free x S. auriculata & 6 & $<0.001^{*}$ \\
E.azurea x S. auriculata & 6 & $<0.001^{*}$ \\
& Plant-free & & \\
\hline & $\begin{array}{l}\text { Light x Dark } \\
\text { E.azurea }\end{array}$ & 12 & 0.157 \\
\hline $\begin{array}{l}\text { Light x Dark } \\
\text { S. auriculata }\end{array}$ & 12 & $<0.001^{*}$ \\
\hline Light x Dark & 12 & $<0.001^{*}$ \\
\hline
\end{tabular}

* indicates statistical difference.

The $\mathrm{pH}$ values showed a slight decrease, especially in the dark condition, ranging from 7.56 to 7.01 in the light and from 7.56 to 6.65 in the dark, in treatments with $E$. azurea and, from 7.56 to 7.08 in the light and 7.56 to 6.67 in the dark in treatments with $S$. auriculata. In the plant-free surface, the $\mathrm{pH}$ values increased from 7.56 to 7.88 in the light and decreased from 7.56 to 7.45 in the dark. The decrease in $\mathrm{pH}$ values indicates the formation of $\mathrm{CO}_{2}$ by heterotrophy. The light intensity in the light condition ranged from 2 to $1100 \mu \mathrm{mol}$ photons $\mathrm{m}^{-2} \mathrm{~s}^{-1}$ and in the dark condition it was not detected.

\section{DISCUSSION}

In this study, the presence of plants significantly promoted a greater loss of $\mathrm{CH}_{4}$ per water volume concomitantly with higher $\mathrm{O}_{2}$ uptake and a lower outflow of $\mathrm{CO}_{2}$ compared to the plant-free surface, supporting our first hypothesis. Moreover, our results indicate a diel variation of methane oxidation and methane emission processes, according to the differences observed between $\mathrm{O}_{2}$ uptake and $\mathrm{CO}_{2}$ outflow, mainly in the dark condition, supporting partially our second hypothesis. In the light condition, differences between plants and plant-free surface were also observed, but were smaller and require confirmation by other studies. We consider that this study identified a role for floating aquatic macrophytes in the methane cycle, which was not considered in studies of greenhouse gases in freshwater ecosystems.

In freshwater ecosystems, methane encounters several zones that oxidize methane before emission. The first methane oxidation zone is the oxygenated rhizosphere of emergent aquatic macrophytes in the sediment, where the methane produced in anoxic sediments diffuses being oxidized by methanotrophic bacteria ${ }^{40}$. The second zone of methane oxidation is the thin superficial oxic layer of sediment ${ }^{41}$. The third zone of methanotrophy is the oxygenated water column ${ }^{42,43,44}$. After that, the remaining $\mathrm{CH}_{4}$ diffuses through the plants and water column to the atmosphere. Our study suggests that the floating aquatic macrophytes are the final zone of methane oxidation before methane emission to the atmosphere, when the plants are present. It is important to note that the aquatic macrophytes are only part of the water-air interface and other processes that influence methane oxidation and emission occur in this boundary layer, such as convective cooling, internal waves and surface organic films. The greater decrease in methane concentration in the treatments with plants resulted probably from methanotrophy in the rhizosphere, according to the associated smallest loss of $\mathrm{CO}_{2}$, which was most likely the result of partial replacement by new $\mathrm{CO}_{2}$ produced during the methanotrophic activity. It is important to note that methanotrophy should be responsible only for part of the $\mathrm{CO}_{2}$ produced, since $\mathrm{CO}_{2}$ is produced by many other heterotrophic processes that can occur simultaneously. The concomitant higher $\mathrm{O}_{2}$ uptake and the decrease in $\mathrm{pH}$ in 
these treatments also indicate the heterotrophic activity with $\mathrm{CO}_{2}$ formation. Previous studies showed the capability of free-floating aquatic macrophytes in transporting oxygen from the foliage to the rhizosphere ${ }^{45}$, 46 . The roots within the water column act as a living substrate for the growth of attached aerobic bacteria, which consume the oxygen to decompose dissolved organic compounds ${ }^{47}$. The absence of a substrate for bacteria in plant-free surface probably promotes a less effective heterotrophic activity, with lower $\mathrm{O}_{2}$ uptake and $\mathrm{CO}_{2}$ production. In Cabiúnas Lagoon, these findings are particularly relevant because the aquatic macrophytes cover $60 \%$ of its area, including floating aquatic macrophytes ${ }^{35}$ and the heterotrophic activity associated with these plants in the water-air interface is being underestimated. Moreover, the sediment of aquatic macrophytes stands showed higher potential $\mathrm{CH}_{4}$ production rate ${ }^{10}$ and higher $\mathrm{CH}_{4}$ concentration ${ }^{48}$ than the limnetic region free of plants in this lagoon. Another four coastal lagoons located in Restinga de Jurubatiba National Park had higher potential $\mathrm{CH}_{4}$ production in aquatic macrophytes stands than in the limnetic region ${ }^{10,19}$, highlighting the importance of aquatic macrophytes in the methane cycle. The natural decrease of methane concentration from the bottom to the surface in the aquatic ecosystems due to the methane consumption processes lead to low methane concentrations near the waterair interface, diminishing the potential of floating aquatic macrophytes in reducing methane concentration. On the other hand, our findings may be particularly important in eutrophic ecosystems. In these ecosystems, the increased amount of organic matter associated with the usual shift to floating aquatic macrophytes covering promotes anoxia below the leaves ${ }^{26,27}$ and a barrier against the efflux of gases ${ }^{23,28}$, increasing the methane concentration in the water column. Therefore, the thin aerobic boundary layer below the leaves of floating aquatic macrophytes may represent an important zone of methane oxidation in these environments.

We did not observe significant differences between methane concentrations in the light and in the dark in the treatments with aquatic macrophytes, despite the greater loss of $\mathrm{CO}_{2}$ (lower $\mathrm{CO}_{2}$ production) and lower consumption of $\mathrm{O}_{2}$ in the light. One of the factors responsible for this result may be the inhibition of methane oxidation by the incidence of light ( 2 to $1100 \mu \mathrm{mol}$ photons $\mathrm{m}^{-2} \mathrm{~s}^{-1}$ ), which could explain not only the greater loss of $\mathrm{CO}_{2}$ (lower $\mathrm{CO}_{2}$ production) as well as the lower $\mathrm{O}_{2}$ consumption. However, the influence of incident light on the inhibition of methanotrophy may have been overestimated in our study, once a single plant was incubated in each glass bottle, allowing an excessive light penetration in the water. In the lagoon, the plants are juxtaposed forming a mat that hampers light penetration. Another factor probably responsible for light attenuation in Cabiúnas Lagoon is the black-colored water ${ }^{36}$ originated from humic substances produced mainly by the decomposition of terrestrial plants from the surrounding sandy soils ${ }^{49}$. The inhibitory effect of light on the activity of methanotrophs has been reported before with increasing light intensities, ranging from a slightly inhibitory effect with low intensities $\left(4.1\right.$ to $21 \mu \mathrm{mol}$ photons $\left.\mathrm{m}^{-2} \mathrm{~s}^{-1}\right)$ to a complete inhibition with higher intensities ( 57 to $760 \mu \mathrm{mol}$ photons $\mathrm{m}^{-2} \mathrm{~s}^{-1}$ ) ${ }^{50,51}$. The absence of methane oxidation in the surface water of a $\mathrm{CH}_{4}$ supersaturated lake was also observed ${ }^{52}$. The proposed mechanism by which light inhibits methane oxidation is the possible photosensitivity of the enzyme methane monooxygenase. Methanotrophs are genetically related to nitrifying bacteria ${ }^{53}$, which has the photosensitive enzyme ammonia monooxygenase ${ }^{54}$. Ammonia monooxygenase and methane monooxygenase are closely related by their substrate specificities, their active sites structures, and their sensitivities to inhibitors ${ }^{55}$. On the other hand, the photosynthetic activity of plants during the light period and, the consequent diffusion of produced $\mathrm{O}_{2}$ into the water could replace the $\mathrm{O}_{2}$ consumed in the other heterotrophic activities, which could explain the lower $\mathrm{O}_{2}$ consumption observed. The processes that occur in the dark 
may act in an opposite way. Higher methane oxidation is expected in the dark, since the methane oxidation inhibition is not observed in this condition. The $\mathrm{O}_{2}$ consumed cannot be refueled due to the absence of photosynthetic activity in the dark.

Our results also suggest that the emission of methane through the plants is controlled by light, concurrently with the control of the oxidation. In the light, the unoxidized methane and the $\mathrm{CO}_{2}$ produced could be emitted by stomata. On the other hand, methane emission is expected to be lower in the dark, since the stomata are closed in this condition. These results suggest a diel variation of methane oxidation and methane emission, depending on the intensity of light in freshwater ecosystems. Diel variation in methane emission by emergent aquatic macrophytes has been observed 56, 57, but the physiological mechanisms that control methane release to the atmosphere from plants are not completely understood. The stomata opening is controlled by factors that present diel variation such as light ${ }^{58}$. Therefore, it is expected that the emission of methane present diel variation. However, while some studies have found a correlation between the emission of methane and opening of stomata ${ }^{59,60}$, other studies did not observe such correlation ${ }^{61,62}$. Stomatal control of methane emission becomes less important as cracks develop in the cuticle of older leaves or damaged leaves that are open to the air ${ }^{63,64}$. A study conducted with emergent plants of Cabiúnas Lagoon indicated that very small damages performed by insects in many culms may considerably increase methane fluxes to the atmosphere ${ }^{20}$. Presumably, methane could not accumulate in these leaves with less resistance to gas flow ${ }^{63,64}$.

Despite no significant differences were observed, $\mathrm{O}_{2}$ consumption in the dark was slightly higher than in the light also in the plant-free surface, concomitant with a smaller loss of $\mathrm{CO}_{2}$, indicating that photosynthetic activity occurred in the light and the heterotrophic activity was higher in the dark, reinforcing the results observed with plants. Therefore, based on the differences observed in light and dark conditions in this study, we suggest that light is an important controlling factor of biological methane oxidation and methane emission primarily in the roots and rhizomes of floating aquatic macrophytes, but also in the plant-free surface.

Several studies have shown that the influence of emergent aquatic macrophytes on methane cycle varies among plant taxa, according to the differences in detritus quality, architecture of lacunar spaces, in oxygen transport mechanisms, and root oxygen demand ${ }^{10,12,19,65,66}$. We believe that variation associated to taxa may occur in floating aquatic macrophytes, since we observed differences in $\mathrm{O}_{2}$ consumption and $\mathrm{CO}_{2}$ outflow for treatments with E. azurea and $S$. auriculata in this study. The extent to which root-associated methane oxidation and emission varies among plant taxa is uncertain. Therefore, a better understanding of such variability is necessary in pristine freshwater ecosystems, but especially in eutrophied environments, since the shifts in aquatic macrophytes communities structures can profoundly affect the relative role of methanogenesis, methanotrophy and methane emission.

\section{CONCLUSION}

In summary, two common species of aquatic macrophytes potentialized the decrease of methane concentration in the water column probably by alternating between the predominance of methane oxidation and methane emission in a diel cycle of methane in coastal lagoons. We suggest that an inhibition of methane oxidation occurs during daylight and the emission to the atmosphere predominates. Overnight methanotrophy prevails, since there is no inhibition by light and the stomata are closed, preventing the emission through the plants. The length variation of day and night throughout the year probably provides a seasonal change in the preponderance of oxidation and emission of methane in the water column of coastal lagoons, particularly in regions 
colonized by floating aquatic macrophytes. Eutrophic environments need special attention because they usually have a wide colonization by floating aquatic macrophytes and high production and concentration of methane. Overall, our findings emphasize the need to include the role played by floating aquatic macrophytes in the biogeochemical cycling of methane as an important component for future predictions of global methane budget.

\section{ACKNOWLEDGEMENTS}

The authors are grateful to Coordenação de Aperfeiçoamento de Pessoal de Nível Superior (CAPES) and Conselho Nacional de Desenvolvimento Científico e tecnológico $(\mathrm{CNPq})$ for financial support.

\section{REFERENCES}

1- Myhre G, Shindell D, Breon F-M, Collins W, Fuglestvedt J, Huang J et al. Anthropogenic and natural radiative forcing. In: Stocker TF, Qin D, Plattner G-K, Tignor M, Allen SK, Boschung J et al., editors. Climate change 2013: the physical science basis. Contribution of working group I to the fifth assessment report of the Intergovernmental Panel on Climate Change. Cambridge, United Kingdom and New York, NY, USA: Cambridge University Press; 2013. p. 659-740.

2- Ciais P, Sabine C, Bala G, Bopp L, Brovkin V, Canadell J et al. Carbon and other biogeochemical cycles. In: Stocker TF, Qin D, Plattner G-K, Tignor M, Allen SK, Boschung J et al., editors. Climate change 2013: the physical science basis. Contribution of working group I to the fifth assessment report of the Intergovernmental Panel on Climate Change. Cambridge, United Kingdom and New York, NY, USA: Cambridge University Press; 2013. p. $465-570$.

3- Segers R. Methane production and methane consumption: a review of processes underlying wetland methane fluxes. Biogeochemistry. 1998; 41:23-51.

4- Bartlett KB, Harriss RC. Review and assessment of methane emission from wetlands. Chemosphere. 1993; 26: 261-320.

5- Vale RS, Alves EG, Santana RA, Totta J, Souza R, Miller S. Conceitos e métodos da transferência de gases na interface água-ar. Rev Bras de Geog Fís. 2015; 8: 1244-1255.

6- Poindexter CM, Baldocchi DD, Matthes JH, Knox SH, Variano EA. The contribution of an overlooked transport process to a wetland's methane emissions. Geophys Res Lett. 2016; 43: 6276-6284.

7- Carmichael MJ, Bernhardt ES, Bräuer SL, Smith WK. The role of vegetation in methane flux to the atmosphere: should vegetation be included as a distinct category in the global methane budget? Biogeochemistry. 2014; 119: 1-24.

8- Esteves FA. Fundamentos de Limnologia, 3rd edn. Rio de Janeiro: Interciência; 2011.

9- Laanbroek HJ. Methane emission from natural wetlands: interplay between emergent macrophytes and soil microbial processes. A mini-review. Ann Bot. 2010; 105:141-153.

10-Petruzzella A, Marinho CC, Sanches LF, Minello M, Esteves FA. Magnitude and variability of methane production and concentration in tropical coastal lagoons sediments. Acta Limnol Bras. 2013; 25: 341-351.

11-Bhullar GS, Edwards PJ, Venterink HO. Influence of different plant species on methane emissions from soil in a restored swiss wetland. PLOS ONE. 2014; 9: 1-5.

12-Marinho CC, Palma-Silva C, Albertoni EF, Giacomini IB, Figueiredo-Barros MP, Furlanetto LM et al. Emergent macrophytes alter the sediment composition in a small, shallow subtropical lake: Implications for methane emission. Am J Plant Sci. 2015; 6: 315322.

13-Lombardi JE, Epp JE, Chanton JP. Investigation of the methyl fluoride technique for determining rhizospheric methane oxidation. Biogeochemistry. 1997; 36: 153-172.

14-Kankaala P, Bergstrom I. Emission and oxidation of methane in Equisetum fluviatile stands growing on organic sediment and sand bottoms. Biogeochemistry. 2004; 67:21-37. 
15-Ström L, Mastepanov M, Christensen TR. Species-specific effects of vascular plants on carbon turnover and methane emissions from wetlands. Biogeochemistry. 2005; 75:65-82.

16-Meng L, Hess PGM, Mahowald NM, Yavitt, Riley WJ, Subin ZM et al. Sensitivity of wetland methane emissions to model assumptions: application and model testing against site observations. Biogeosciences. 2012; 9: 2793-2819.

17-Whiting GJ, Chanton JP, Bartlett DS, Happell JD. Relationships between $\mathrm{CH}_{4}$ emission, biomass, and $\mathrm{CO}_{2}$ exchange in a sub-tropical grassland. J Geophys Res. 1991; 96:1306713071.

18-Greenup AL, Bradford MA, McNamara NP, Ineson P, Lee JA. The role of Eriophorum vaginatum in $\mathrm{CH}_{4}$ flux from an ombrotrophic peatland. Plant Soil. 2000; 227:265-272.

19-Fonseca ALS, Marinho CC, Esteves FA. Aquatic macrophytes detritus quality and sulfate availability shape the methane production pattern in a dystrophic coastal lagoon. Am J Plant Sci. 2015; 6: 1675-1684.

20-Petruzzella A, Guariento RD, Gripp AR, Marinho CC, Figueiredo-Barros MP, Esteves FA. Herbivore damage increases methane emission from emergentaquatic macrophytes. Aquat Bot. 2015; 127: 6-11.

21-Portielje R, Roijackers RMM. Primary succession of aquatic macrophytes in experimental ditches in relation to nutrient input. Aquat Bot. 1995; 50: 127-140.

22-Scheffer M, Szabo S, Gragnani A, van Nes EH, Rinaldi S, Kautsky N et al. Floating plant dominance as a stable state. Proc Natl Acad Sci USA. 2003; 100: 4040-4045.

23-Pierobon E, Bolpagni R, Bartoli M, Viaroli P. Net primary production and seasonal $\mathrm{CO}_{2}$ and $\mathrm{CH}_{4}$ fluxes in a Trapa natans L. meadow. J Limnol. 2010; 69: 225-234.

24-Ribaudo C, Bartoli M, Longhi D, Castaldi S, Neubauer SC, Viaroli P. $\mathrm{CO}_{2}$ and $\mathrm{CH}_{4}$ fluxes across a Nuphar lutea (L.) Sm. Stand. J Limnol. 2012; 71: 200-210.

25-Pokorny J, Rejmankova E. Oxygen regime in a fishpond with duckweeds (Lemnaceae) and Ceratophyllum. Aquat Bot. 1983; 17: 125-137.

26-Frodge JD, Thomas GL, Pauley GB. Effects of canopy formation by floating and submergent aquatic macrophytes on the water quality of two shallow Pacific Northwest lakes. Aquat Bot. 1990; 38:231-248.

27-Parr LB, Perkins RG, Mason CF. Reduction in photosynthetic efficiency of Cladophora glomerata, induced by overlying canopies of Lemna spp. Water Res. 2002; 36: 1735-1742.

28-Bolpagni R, Pierobon E, Longhi D, Nizzoli D, Bartoli M, Tomaselli M, Viaroli P. Diurnal exchanges of $\mathrm{CO}_{2}$ and $\mathrm{CH}_{4}$ across the water-atmosphere interface in a water chestnut meadow (Trapa natans L.). Aquat Bot. 2007; 87: 43-48.

29-Strayer DL, Findlay SEG. Ecology of freshwater shore zones. Aquat Sci. 2010; 72:127163.

30-Junk WJ. Current state of knowledge regarding South America wetlands and their future under global climate change. Aquat Sci. 2013; 75:113-131.

31-Lloret J, Marín A, Marín-Guirao L. Is coastal lagoon eutrophication likely to be aggravated by global climate change? Estuar Coast Shelf S. 2008; 78: 403-412.

32-Brito AC, Newton A, Tett P, Fernandes TF. How will shallow coastal lagoons respond to climate change? A modelling investigation. Estuar Coast Shelf S. 2012; 112: 98-104.

33-Panosso RF, Attayde JL, Muehe D. Morfometria das lagoas Imboassica, Cabiúnas, Comprida e Carapebus: Implicações para seu funcionamento e manejo. In: Esteves FA, editor. Ecologia das lagoas costeiras do Parque Nacional da Restinga de Jurubatiba e do Município de Macaé (RJ). Rio de Janeiro: NUPEM/UFRJ; 1998. p. 91.

34-Caliman A, Carneiro LS, Santangelo JM, Guariento RD, Pires APF, Suhett AL et al. Temporal coherence among tropical coastal lagoons: a search for patterns and mechanisms. Braz J Biol. 2010; 70: 803-814.

35-Gripp AR, Marinho CC, Sanches LF, Petruzzella A, Esteves FA. The role played by aquatic macrophytes regarding $\mathrm{CO}_{2}$ balance in a tropical coastal lagoon (Cabiúnas Lagoon, Macaé, RJ). Acta Limnol Bras. 2013; 25: 291-301.

36-Furtado ALS, Casper P, Esteves FA. Methanogenesis in an Impacted and Two Dystrophic Coastal Lagoons (Macaé, Brazil). Braz Arch Biol Techn. 2002; 45; 195-202.

37-Marinho CC, Fonseca ALS, Minello M, Esteves FA. Resultados e perspectivas sobre o estudo do metano nas lagoas costeiras da Restinga de Jurubatiba e na Lagoa Imboassicana região Norte do Estado do Rio de janeiro. In: Rocha CFD, Esteves FA, Scarano FR, 
organizers. Pesquisas de longa duração na Restinga de Jurubatiba: Ecologia, história natural e conservação. São Carlos: RiMa; 2004. p. 273-294.

38-Carmouze JP. O metabolismo dos ecossistemas aquáticos: fundamentos teóricos, métodos de estudo e análises químicas. São Paulo: Edgar Blücher Ltda/FAPESP; 1994.

39-Gran G. Determination of equivalent point in potentiometric titration. Analyst. 1952; 77: 661-671.

40-King GM. Associations of methanotrophs with the roots and rhizomes of aquatic vegetation. Appl Environm Microb. 1994; 60: 3220-3227.

41-Frenzel P, Thebrath B, Conrad R. Oxidation of methane the oxic surface layer of a deep lake sediment (Lake Constance). FEMS Microbiol Ecol. 1990; 73:149-158.

42- Guérin F, Abril G. Significance of pelagic aerobic methane oxidation in the methane and carbon budget of a tropical reservoir. J Geophys Res. 2007; 112: G03006.

43-Zigah PK, Oswald K, Brand A, Dinkel C, Wehrli B, Schubert CJ. Methane oxidation pathways and associated methanotrophic communities in the water column of a tropical lake. Limnol Oceanogr. 2015; 60: 553-572.

44-Roland FAE, Darchambea Fu, Morana C, Borges AV. Nitrous oxide and methane seasonal variability in the epilimnion of a large tropical meromictic lake (Lake Kivu, EastAfrica). Aquat Sci. 2016; DOI 10.1007/s00027-016-0491-2.

45-Moorhead KK, Reddy KR. Oxygen transport through selected aquatic macrophytes. $J$ Environ Qual. 1988; 17: 138-142.

46-Reddy KR, D’Angelo, DeBusk TA. Oxygen transport through aquatic macrophytes: The role in wastewater treatment. J Environ Qual. 1989; 19: 261-267.

47-Hastie BA. The use of aquatic plants in wastewater treatment: a literature review. Faculty of the Civil Engineering report. Texas: University of Texas at Austin; 1992.

48-Fonseca ALS, Minello M, Marinho CC, Esteves FA. Methane concentration in water column and in pore water of a coastal lagoon (Cabiúnas lagoon, Macaé, RJ, Brazil). Braz Arch Biol Technol. 2004; 47: 301-308.

49-Suhett AL, Amado AM, Meirelles-Pereira F, Scofield V, Jacques SMS, Laque T, Farjalla VF. Origin, concentration, availability and fate of dissolved organic carbon in coastal lagoons of the Rio de Janeiro State. Acta Limnol Bras. 2013; 25: 326-340.

50-Dumestre JF, Guézennec J, Galy-Lacaux C, Delmas R, Richard S, Labroue L. Influence of light intensity on methanotrophic bacterial activity in Petit Saut Reservoir, French Guiana. Appl Environ Microbiol. 1999; 65: 534-539.

51-Murase A, Sugimoto A. Inhibitory effect of light on methane oxidation in the pelagic water column of a mesotrophic lake (Lake Biwa, Japan). Limnol Oceanogr. 2005; 50:13391343.

52-Blees J, Niemann H, Erne M, Zopfi J, Schubert CJ, Lehmann MF. Spatial variations in surface water methane super-saturation and emission in Lake Lugano, southern Switzerland. Aquat Sci. 2015; 77: 535-545.

53-Holmes AJ, Costello A, Lidstrom ME, Murrell JC. Evidence that particulate methane monooxygenase and ammonia monooxygenase may be evolutionarily related. FEMS Microbiol Lett. 1995; 132: 203-208.

54-Shears JH, Wood PM. Spectroscopic evidence for a photosensitive oxygenated state of ammonia mono-oxygenase. Biochem J. 1985; 226: 499-507.

55-Bédard C, Knowles R. Physiology, biochemistry, and specific inhibitors of $\mathrm{CH}_{4}, \mathrm{NH}_{4}^{+}$, and CO oxidation by methanotrophs and nitrifiers. Microbiol Rev. 1989; 53: 68-84.

56-Chanton JP, Arkebauer TJ, Harden HS, Verma SB. Diel variation in lacunal $\mathrm{CH}_{4}$ and $\mathrm{CO}_{2}$ concentrations and $\delta 13 \mathrm{C}$ in Phragmites australis. Biogeochemistry. 2002; 59: 287-301.

57-Ding W, Cai Z, Wang D. Preliminary budget of methane emissions from natural wetlands in China. Atmos Environ. 2004; 38:751-759.

58-Lambers H, Capin III SF, Pons TL. Plant physiological ecology. New York: SpringerVerlag; 1998.

59-Frye JP, Mills AL, Odum WE. Methane flux in Peltandra virginica (Araceae) wetlands: comparison of field data with a mathematical model. Am J Bot. 1994; 81: 407-413.

60-Thomas KL, Benstead J, Davies KL, Lloyd D. Role of wetland plants in the diurnal control of $\mathrm{CH}_{4}$ and $\mathrm{CO}_{2}$ fluxes in peat. Soil Biol Biochem. 1995; 28: 17-23.

61-Nouchi I, Mariko S, Aoki K. Mechanism of methane transport from the rhizosphere to the atmosphere through rice plants. Plant Physiol. 1990; 94: 59-66. 
62-Whiting GJ, Chanton JP. Control of the diurnal pattern of methane emission from emergent aquatic macrophytes by gas transport mechanisms. Aquat Bot. 1996; 54: 237-253. 63-Yavitt JB, Knapp AK. Aspects of methane flow from sediment through emergent cattail (Typha latifolia) plants. New Phytol. 1998; 139: 495-503.

64-Morin TH, Bohrer G, Frasson RPdM, Naor-Azreli L, Mesi S, Stefanik KC, Schäfer KVR. Environmental drivers of methane fluxes from an urban temperate wetland park. J Geophys Res Biogeosci. 2014; 119: 2188-2208.

65-Sorrell BK, Boon PI. Convective gas flow in Eleocharis sphacelata R. Br.: methane transport and release from wetlands. Aquat Bot. 1994; 47: 197-212.

66-Ding W, Cai A, Tsuruta. Plant species effects on methane emissions from freshwater marshes. Atmos Environ. 2005; 39: 3199-3207.

Received: February 03, 2016; Accepted: July 14, 2016 